\title{
Interactive effects of fire, rainfall and litter quality on decomposition in savannas: frequent fire leads to contrasting effects
}

Andrew B. Davies ${ }^{1,}$, Berndt J. van Rensburg ${ }^{1,2}$, Paul Eggleton ${ }^{3}$ and Catherine L. Parr ${ }^{4,5}$

\begin{abstract}
${ }^{1}$ Centre for Invasion Biology, Department of Zoology and Entomology, University of Pretoria, Pretoria, 0002, South Africa, ${ }^{2}$ School of Biological Sciences, University of Queensland, St. Lucia, QLD 4072, Australia, ${ }^{3}$ Soil Biodiversity Group, Life Sciences Department, The Natural History Museum, Cromwell Road, London, SW7 5BD, United Kingdom, ${ }^{4}$ Environmental Change Institute, School of Geography and the Environment, Oxford University Centre for the Environment, South Parks Road, Oxford, OX1 3QY, United Kingdom, ${ }^{5}$ School of Environmental Sciences, University of Liverpool, Liverpool, L69 3GP, United Kingdom
\end{abstract}

\footnotetext{
"Corresponding author: Andrew Davies - Centre for Invasion Biology, Department of Zoology and Entomology, University of Pretoria, Pretoria, 0002, South Africa. Telephone: +27 12420 4627; Fax: +27 12362 5242; e-mail: abdavies@zoology.up.ac.za
}

\begin{abstract}
One of the many ecological processes expected to undergo alteration due to global change is the decomposition of organic matter, with little known concerning the effects that changing disturbance regimes may have. Fire, a critical process in many habitats, is expected to become more common. We measured the decomposition rates of four grass species that differed in litter quality, investigating them under different fire regimes across a savanna rainfall gradient in South Africa. We also collected data on the abundance and activity of fungus-growing termites and recorded measurements of temperature and canopy cover. Overall, decomposition rate followed global models, increasing under warmer and wetter
\end{abstract}


conditions. Litter quality was also significant with higher quality grasses decomposing faster; however, this effect was less pronounced than expected. Fire regimes did not have a consistent effect on decomposition rate along the rainfall gradient. In the most arid savanna type examined, fire had no effect, whereas in the intermediate-rainfall savanna burning increased decomposition rate under higher levels of fungus-growing termite activity. In the wetter savannas, fire slowed decomposition, possibly through modification of vegetation structure and potential effects on other invertebrates. Our results demonstrate that grass decomposition in African savannas varies significantly along precipitation gradients, with different factors becoming influential in different habitats. Importantly, we demonstrate that fire does not always act to slow decomposition and that it interacts with other factors to influence the process. These findings have important implications for decomposition in the light of global change models that predict wetter climates and a higher frequency of fires for southern African savannas.

Keywords: burning; crude protein content; disturbance; global change; grass decomposition; mean annual precipitation; termites

\section{Introduction}

Understanding how ecosystem functioning will be affected by global change has attracted much interest and concern. One function likely to change considerably is the decomposition of organic matter, a critical ecological process essential for nutrient cycling (Swift and others 1979; Sayer 2006), in particular for returning carbon fixed by plants during photosynthesis to the atmosphere (Schimel and others 1996; Hättenschwiler and others 2005). Much literature exists examining how litter decomposition varies with, and is driven by, climate (Couteaûx and others 1995; Taylor and others 2004), however far less well understood is how changes 
in the frequency of disturbance phenomena, such as fire, will affect the process (Brennan and others 2009).

Fire is a widespread disturbance in many ecosystems across the globe (Chapin and others 2002), where it acts to alter vegetation structure and composition (Bond and Keeley 2005), nutrient cycling (Van de Vijver and others 1999) and aboveground net primary productivity (Buis and others 2009). Effects of fire on ecosystem functioning therefore cannot be ignored and changing fire regimes may be even more influential than the direct effects of a changing climate (Flannigan and others 2000; Brennan and others 2009). However, the influence of fire on many ecological dynamics and processes, ranging from biodiversity (Parr and Chown 2003; Davies and others 2010) to ecosystem functioning (Bond and others 2005) is thus far poorly understood.

It is generally accepted that in many fire-prone biomes across the globe the frequency of fires will increase under global climate change. This due to, among other things, an increase in fuel load and aridity caused by increasing $\mathrm{CO}_{2}$ and temperature levels, decreasing rainfall and relative humidity (Hughes 2003), and an increase in lighting strikes in some areas (Goldammer and Price 1998; Cary 2002). Furthermore, more frequent fires are expected as a result of increasing human populations in many parts of the world (Williams and others 2009). This suggests that a clearer understanding of how fire affects important ecosystem functions, such as decomposition, is necessary if we are successfully to anticipate and mitigate effects of future global change (Krawchuk and others 2009).

The main direct agents of decomposition are decomposer organisms: predominantly fungi, bacteria, and soil/litter invertebrates, although some breakdown of dead plant material is caused by photodegradation. At global scales, the rate of decomposition by these decomposer agents is principally mediated by climate (rainfall and temperature), and secondarily litter quality (chemical composition) (Lavelle and others 1993; Couteaûx and 
others 1995; Aerts 1997). Decomposition is thought to be predominantly a microbial process, with important contributions made by invertebrates when conditions are suitable, with climate creating the conditions (temperature and moisture levels) under which decomposition occurs. Under extremes of temperature and moisture, decomposition takes place slowly because microbial communities are sensitive to such extremes (becoming inactive under unfavourable conditions) (Couteaûx and others 1995). Litter quality defines how important the substrate material is to the microbial community (Murphy and others 1998) and hence influences the rate of decomposition. Soil/litter animals, when they are relatively abundant, in turn enhance decomposition through direct consumption of dead plant material, litter comminution and soil mixing, increasing surface area for microbes and bringing them into contact with litter (Couteaûx and others 1995). However, faunal communities are even more constrained than microbial communities by climatic factors and litter quality, and are therefore often only considered important in ecosystems that are unconstrained by temperature and moisture availability (Lavelle and others 1993; Wall and others 2008). Furthermore, because most decomposition models assume that all decomposition is microbial, they focus solely on climate and litter quality (Meentemeyer 1978; Rastetter and others 1991; Gholz and others 2000), with little regard to other factors such as soil animals and disturbance phenomena.

At local and regional scales other factors have been shown to have a significant influence on decomposition (Wall and others 2008; Powers and others 2009). These factors include soil animals (Whitford and others 1982; Schuurman 2005), photodegradation in arid regions (Austin and Vivanco 2006; Brandt and others 2010; Austin 2011), litter type interactions (Hättenschwiler and Gasser 2005), and the "home-field advantage" hypothesis, whereby litter decomposes faster under cover of the same species it is derived from (e.g. Ayres and others 2009). At such regional scales, disturbances such as fire may also play an 
important role through interactions with other mediating factors. Several studies have shown that frequent burning slows decomposition rates through a variety of mechanisms. In Eucalyptus forest, Brennan and others (2009) attributed slower rates of decomposition to negative effects of frequent fire on invertebrate decomposer abundance, while in seasonal Amazonian forest repeated burning was thought to have slowed decomposition rates through altered micro-climatic conditions (particularly by increasing temperature and decreasing relative humidity, resulting in a drier environment) (Silveira and others 2009). Other potential mechanisms include interactions with herbivory (Kay and others 2008), and long-term alterations of litter quality by fire (Hernández and Hobbie 2008).

The majority of decomposition studies (both global and regional) have taken place in forested areas, with fewer in grassy biomes, despite these biomes being globally dominant habitats (Bond and Parr 2010). The few decomposition studies from grassy systems have shown that drivers vary regionally, with, for example, photodegradation playing larger roles in arid than mesic regions (Brandt and others 2010). Tian and others (2007) measured decomposition as a function of climate and litter quality along a rainfall gradient from rainforest to the Sahel in west Africa (including grassy systems) and found the two factors to interact in their influence: high quality grasses decomposed more rapidly in wetter environments while low quality grasses decomposed faster in dry areas. They attributed this effect to higher termite abundance and increased photodegradation in arid regions.

Decomposition work in savannas (which extend over more than half the African continent and range from mesic, humid habitats to semi-arid ones (Scholes and Archer 1997)) has also demonstrated the important role played by soil fauna, in particular termites (Ohiagu and Wood 1979; Collins 1981; Schuurman 2005; Freymann and others 2010; Buitenwerf and others 2011). However the lack of published studies across environmental gradients, particularly in relation to potential effects of disturbance phenomena such as fire on 
decomposition, means decomposition processes in African savannas remain poorly understood. In the current study, grass decomposition rates were investigated along environmental gradients in southern African savannas. We examined differences in decomposition rates at four sites along an extended rainfall gradient during two seasons to (1) investigate the influence of climate; (2) litter quality and (3) long-term fire regimes, on decomposition, including how fire interacts with climate and litter quality. To explore potential mechanisms underlying the effects of fire, we collected data on the abundance and activity of a major decomposer animal group (fungus-growing termites) as well as other explanatory variables that have previously been shown to be important (temperature and canopy cover). While we were unable to tease apart the direct mechanisms of the patterns observed based on our data, we do suggest testable hypotheses for the main factors influencing decomposition across the rainfall gradient.

In line with global models, we expected to find faster rates of decomposition in wetter savannas and during the wet season due to increased temperatures and moisture availability favouring microbial communities and soil animals. We also expected high quality grasses to decompose faster, irrespective of climate, as soil animals and microbes would be better able to break them down. The effect of frequent burning was expected to decrease decomposition rates through interactions with other mediating factors such as decomposer organisms and microclimatic conditions, as found in previous studies (see for e.g. Brennan and others 2009; Silveira and others 2009); but this effect was expected to interact with mean annual precipitation, being more influential in wetter areas where fire effects are more noticeable (see for e.g. Parr and others 2004; Davies and others 2012).

\section{Methods}

Study site 
The experiment was undertaken in four distinct savanna types across two of South Africa's major reserves: Kruger National Park (KNP, $\left.22^{\circ} 25^{\prime}-25^{\circ} 32^{\prime} \mathrm{S} ; 30^{\circ} 50^{\prime}-32^{\circ} 02^{\prime} \mathrm{E}\right)$ and Hluhluwe-iMfolozi Park (HiP, $\left.28^{\circ} 01^{\prime}-28^{\circ} 25^{\prime} \mathrm{S} ; 32^{\circ} 15^{\prime}-32^{\circ} 26^{\prime} \mathrm{E}\right)$. These sites are spread over a distance of $c a .700$ kilometres and are situated along a rainfall gradient from 450 mm. $\mathrm{yr}^{-1}$ in the north to $900 \mathrm{~mm} . \mathrm{yr}^{-1}$ in the south. The two parks are located in the eastern part of South Africa and have a sub-tropical climate with a distinct summer rainfall pattern.

The four savanna types, in ascending order of mean annual rainfall, were: Colophospermum mopane savanna (Mopani, northern KNP, $450 \mathrm{~mm}$ mean annual precipitation (MAP)), Acacia savanna (Satara, central KNP, 550 mm MAP), Terminalia savanna (Pretoriuskop, southern KNP, 750 mm MAP) and mesic Acacia savanna (Hluhluwe, northern HiP, 900 mm MAP). Sampling in KNP was carried out on a series of long-term experimental burning plots; enabling us to test for effects of long-term burning regimes on decomposition rates. Because no such formal burning experiment exists in HiP, fire map records were used to identify sites in the landscape with fire histories that, as best as possible, match those of the burn plots utilised in KNP (i.e., areas burnt with low and high fire frequency). Six replicated sampling plots (except for Hluhluwe where four plots were used) were selected from within each of the four savanna habitats. Of these six plots, three in each savanna type have been burnt on a triennial basis during the late dry season (August) since 1954 and the other three have remained essentially unburnt for the same time period. Each plot is approximately 7 ha in size and protected from outside fires by a double fire break. The plots are located within a string of other plots subjected to different fire regimes, thus in our study, each burnt plot is paired to an unburnt one, with such pairs spaced $10-20 \mathrm{~km}$ apart (for more information on this fire experiment see Biggs and others 2003). The plots at Satara and Pretoriuskop are on the same burning cycle, while Mopani is a year ahead, meaning that plots at Mopani were burnt a year earlier. At Hluhluwe, reliable estimates of time-since-fire 
are difficult to obtain. However, previous work (Parr and others 2004; Radford and Andersen 2012) has shown that time-since-fire is only relevant for the first few months, after this vegetation regrows and differences disappear. Thus time-since-fire was not considered as important for this study as the burning regime.

\section{Grass species, litter collection and treatment}

Four grass species of differing quality were used in the study (Table 1). Grass quality was measured according to crude protein content and general palatability. Crude protein is known to be necessary for many ungulates to maintain normal physiological functions (Bowers 2006), and although its importance for invertebrates and microbes involved in decomposition is less clear, it does provide a general estimate of litter quality (Radford and Andersen 2012). The four selected grass species can be ranked on a gradient of litter quality by their crude protein content and palatability: (1) Urochloa mosambicensis (highest quality), (2) Cenchrus ciliaris, (3) Themeda triandra and (4) Cymbopogon excavatus (lowest quality) (Table 1).

Plant material was harvested from KNP during May 2008 for the dry season experiment and January 2010 for the wet season experiment. As far as possible each species was harvested from the same location to minimise variation in chemical composition between samples. After harvesting, grass material was cut into segments of approximately $5 \mathrm{~cm}$, mixing stems, inflorescences, green and dried leaves, and placed in brown paper bags. The material was then taken to the laboratory and dried at $60^{\circ} \mathrm{C}$ for 48 hours. After drying, $8-10$ grams of grass material was placed in individually numbered litter bags, measuring $200 \mathrm{~mm} \mathrm{x}$ $200 \mathrm{~mm}$, constructed from aluminium mesh with a mesh size of approximately $2 \mathrm{~mm} \times 2$ $\mathrm{mm}$. This material allowed enlargement of the holes relatively easily to aid access by soil animals such as the larger termite genera. Each bag was then placed in the field, using a nail at opposite corners to secure it to the ground. During each placement the ground surface was 
cleared of grass or leaf litter to ensure the bag was in direct contact with the soil. For the dry season experiment, bags were placed during the austral winter in June 2008 and for the wet season experiment, placement was during the austral summer in January 2010.

\section{Experimental design}

Litter bags were placed in sets of four during the dry season when decomposition was expected to be slower, and three during the wet season. At monthly intervals, one bag from each set was removed with minimal disturbance to the surrounding bags, hence the experiment lasted four months during the dry season and three months during the wet season when decomposition was expected to be faster. Each set consisted of bags containing the same species placed adjacent to each other. These sets (of either four or three bags depending on the season) were placed on the experimental burning plots in a grid formation of six by four sets (24 sets per plot). Each set was spaced 10 metres apart. Species sets of bags were alternated so that at no point were two sets of the same species adjacent to each other in the grid. There were therefore 96 bags on each plot during the dry season $(n=2112)$ and 72 bags per plot in the wet season $(n=1584)$, with six bags from each grass species collected each month (24 bags collected per month).

After collection, the litter bags were placed in paper bags and taken to the laboratory where they were oven dried for 48 hours at $60^{\circ} \mathrm{C}$. Many bags were sufficiently dry during the dry season and hence drying in an oven was not necessary, however, all wet season samples and dry season samples where moisture was present, were dried. After drying, all material was removed from the bags and the grass was manually separated from any foreign plant material, soil or gallery material taken into the bags by termites. Following this, the grass was weighed and the amount remaining measured. 


\section{Additional biotic and environmental measurements}

In addition to measuring decomposition rate with litter bags, we collected data on fungusgrowing termite (a major invertebrate decomposer in African savannas) abundance and activity using cellulose baits. During the wet season, when termites are more active (DawesGromadzki and Spain 2003; Davies 2010), 40 toilet rolls (baits) were placed on each experimental plot in an eight by five grid formation. Half (20) of these baits were buried $2 \mathrm{~cm}$ below the ground and the other half placed on the surface, secured with an aluminium tent peg and wrapped with tape to prevent unravelling (La Fage 1973). At pre-determined time intervals of 5, 14, 28 and 56 days after placement, baits (five buried and five surface at each sampling interval) were removed and inspected for termites. Abundance of termites per plot was defined as the number of termite encounters, with a single encounter defined as one attacked bait (due to difficulties in counting all the termites at a particular bait). The intensity of termite foraging activity was assessed by assigning each bait a score based on the intensity of termite attack, following Dawes-Gromadzki (2003): 0 = no evidence of attack, $1=1-$ $24 \%$ of bait consumed, $2=25-49 \%$ consumed, $3=50-74 \%$ consumed, $4=75-99 \%$ consumed and 5 = bait completely consumed. Hourly temperature readings were also recorded in each savanna site for burnt and unburnt sites using Thermochron iButtons ${ }^{\circledR}$ (Maxim/Dallas Semiconductor Corp., USA) placed approximately $2 \mathrm{~cm}$ below the soil surface. Finally, canopy cover on each experimental burn plot was estimated during the wet season by placing twenty $1 \times 1$ metre quadrats in a grid of five by four quadrats in the centre of each plot and visually estimating canopy cover above each quadrat.

\section{Data analysis}

The amount of grass remaining in each bag after collection was used to calculate the decomposition constant $k$ assuming the exponential decomposition model (Olson 1963), i.e. 
$W_{t}=W_{0} e^{-k t}$

where $W_{0}$ is the amount of grass at the start of the experiment and $W_{t}$ the amount of grass at time $t$. In this case we calculated the constant $k$ with the unit month ${ }^{-1}$ and it was calculated for each litter bag for each month. This variable was then used for the statistical analysis.

In order to avoid spatial autocorrelation, litter bags from each species from each plot were pooled to produce a mean organic mass remaining at collection for each experimental plot per grass species. The decomposition rates in relation to potential explanatory variables (mean annual precipitation (hereafter referred to as precipitation), season, litter quality and fire regime) and the interactions between them were then analysed using a generalised linear model (GLM), corrected for overdispersion, with a Poisson error distribution and log-link function. Model fit was assessed for goodness of fit, homogeneity of variance and normality of residuals using model-checking plots (observed vs. fitted values, residuals vs. fitted values, QQ plots, scale-location plots and residual-leverage plots).

Differences in termite abundance and intensity of termite attack across the two fire regimes in each savanna site were assessed with Wilcoxon signed-rank tests. In order to compare differences in recorded hourly temperature, Student's t tests were applied. Differences in canopy cover across fire regimes were compared with Wilcoxon signed-rank tests. All statistical analyses were performed in the software package R, version 2.11.1 (R development core team 2010).

\section{Results}

Variation along climatic and litter quality gradients

The GLM revealed that precipitation, season and litter quality had a significant effect on the decomposition constant $(k)$ recorded, and hence on the rate of grass decomposition (Table 2). Overall, our recorded rates were very slow, with decomposition being the slowest at the driest 
site (Mopani) and the most rapid at the wettest site (Hluhluwe); this was the case for all grass species (Figs. 1, 2). Decomposition rates were intermediate at Satara (semi-arid to intermediate precipitation) and Pretoriuskop (intermediate to higher precipitation), although the decomposition rate of the highest quality grass (U. mosambicensis) was similar at Satara and Hluhluwe (Figs. 1, 2). Compared with the dry season, decomposition proceeded significantly more rapidly during the wet season, and differences between savanna site and grass species were easier to detect during this season (Table 2, Figs. 1, 2). In all savanna types and both seasons, U. mosambicensis decomposed the fastest and there was a trend of increased decomposition with increasing precipitation (Figs. 1, 2). C. excavatus was the second most removed species, although removal was markedly less than U. mosambicensis.

The interaction between precipitation and season was close to significant $(\mathrm{p}=0.08)$, indicating that season had a stronger effect on decomposition under some precipitation regimes (i.e. savanna types) than others (Table 2). This stronger effect was evident at the intermediate to high rainfall savannas while at the driest savanna (Mopani) seasonal effects were not present (Figs. 1 and 2). Similarly, the interaction between precipitation and litter quality was significant (Table 2), meaning that the rate at which certain grass species decomposed relative to the others depended on the precipitation regime. This is clear when $U$. mosambicensis is considered: it decomposed at a similar rate to the other grass species at Mopani (the driest site) but at much faster rates at all other savanna sites (Figs. 1 and 2). The interaction between litter quality and season was also significant (Table 1), which is most likely because the litter that does not decay rapidly in the wet season (T. triandra and $C$. ciliaris) does not decompose any slower in the dry season. However, the litter that decomposed faster in the wet season (especially U. mosambicensis) decomposed much more slowly in the dry season, hence the significant interaction term (Figs. 1 and 2). Therefore, 
different seasonal effects for different grass litter types are present, but are driven by the low quality grasses displaying no clear seasonal patterns, rather than high quality litter which do.

\section{Effects of fire regime on decomposition}

Although the GLM showed that overall fire regime did not have a significant effect on decomposition rates (all grass species and precipitation regimes combined), there were significant interactions between fire and precipitation, i.e. savanna site, and fire and litter quality (Table 2). Thus, fire regime (triennially burnt vs. long unburnt) affects decomposition rates at some savanna sites, but not others, and also affects decomposition rates of some grass species but not others. Decomposition rates were higher on unburnt plots in the wet savannas for some grass species at Pretoriuskop and all species at Hluhluwe, while the opposite was recorded in the intermediate-arid savanna, Satara: here there were significantly faster rates of decomposition on burnt sites (Fig. 3) for U. mosambicensis (and to a lesser extent $C$. excavatus). At the most arid site (Mopani), no differences were recorded.

\section{Additional biotic and environmental measurements}

Termite abundance did not differ significantly across burning regimes in any of the savanna types (Fig. 4a). However, intensity of termite attack was significantly higher $(\mathrm{W}=9.75, \mathrm{p}<$ 0.05) on burnt sites at Satara (intermediate-arid savanna), but did not differ significantly in any other savanna type (Fig. 4b). Hourly temperature differed significantly between fire regimes at all sites except Pretoriuskop (Mopani: $\mathrm{t}=-5.63, \mathrm{p}<0.001$; Satara: $\mathrm{t}=-8.12, \mathrm{p}<$ 0.001; Pretoriuskop: $\mathrm{t}=-0.39, \mathrm{p}=0.70$; Hluhluwe: $\mathrm{t}=6.15, \mathrm{p}<0.001)$. At the dry sites (Mopani and Satara) temperatures were higher on burnt sites while at the wettest site (Hluhluwe), higher temperatures were recorded on unburnt sites (Fig. 4c). Canopy cover 
differed significantly only at Pretoriuskop (a wet savanna) with greater cover on unburnt sites $(\mathrm{W}=1318, \mathrm{p}<0.001$, Fig. $4 \mathrm{~d})$

\section{Discussion}

A striking finding from our study is the mostly very slow rates of absolute decomposition recorded for grass litter. Although such slow rates could be attributable to the relatively short temporal scale of our study (following the exponential decay model (Olson 1963)), they do reflect patterns for low quality (i.e. highly refractory) grass decomposition. Such slow turnover rates will result in organic matter persisting in the system for a long time: this underscores the importance of single fire events for removal of dead grass and litter in savannas, particularly in the dry season when decomposition is particularly slow.

\section{Decomposition along the rainfall and litter quality gradients}

Our results generally support global decomposition models that suggest climate and litter quality have a dominant effect on the agents of decomposition and therefore decomposition rates (Meentemeyer 1978; Lavelle and others 1993; Couteaûx and others 1995; Gholz and others 2000). Faster rates of decomposition were recorded at the wet sites (Pretoriuskop and Hluhluwe), which is in line with predictions. Similarly, decomposition during the wet season was generally faster at all savanna sites and for all grass species. These results point to an overarching influence of climate over the agents of savanna decomposition, with higher levels of mean annual precipitation, and hence moisture, as well as higher temperatures during the summer wet season, leading to increased decomposition rates. In addition, faunal decomposers, such as earthworms and termites, are sensitive to moisture and temperature levels (Smith and Rust 1994; Curry 1998), becoming less active in cold and dry environments. They are consequently more active during the wet season (Garnsey 1994; 
Dawes-Gromadzki and Spain 2003; Davies 2010). Warmer and wetter areas (as well as the wet season) are therefore more conducive to high decomposer diversity and activity, potentially contributing to faster rates of decomposition in such areas and seasons.

An exception, however, to this climate driven model of decomposition is our recorded rates at Satara, a semi-arid savanna receiving intermediate rainfall. Here decomposition proceeded at similar rates comparable, or even faster in some cases, to Pretoriuskop, a savanna receiving markedly more rainfall. Although not explicitly tested for, a plausible explanation is that this unexpectedly higher rate of decomposition may be due to higher abundance of fungus-growing termites at Satara (Fig. 4a, Davies and others 2012). Fungusgrowing termites have been shown to be important decomposers in savannas (Collins 1981; Holt and Coventry 1990), contributing up to $60 \%$ of wood litter removal (Collins 1981). Indeed Schuurman (2005) found that in a semi-arid Botswana savanna with similar annual rainfall to Satara, variation in fungus-growing termite abundance was the only factor affecting decomposition rates, and hence the potentially important role they play as decomposers in these savannas cannot be ignored. Although no direct data on termite decomposition are available for this study, given that other studies have highlighted the importance of termites in African savannas, we hypothesise that the higher than expected decomposition rates at Satara are suggestive of a termite mediated role. Future research testing more explicitly the role of termites in savanna decomposition is, however, necessary.

Overall differences in decomposition rates between grass species (litter quality) partially followed our predictions. The highest quality grass, U. mosambicensis, (i.e., with the highest crude protein content) decomposed fastest in all savanna types. However, the decomposition rate of $C$. excavatus, the species considered to have the lowest litter quality for our study, was the second fastest and hence went against our predictions. C. excavatus contains high levels of terpenes and is subsequently usually considered unpalatable (Ellis 
1990). The faster than expected decomposition of this species indicates that secondary metabolites (terpenes in this case) may be of less importance in savanna decomposition than anticipated. Bengtsson and others (2011) also found secondary metabolites to have minimal effect on decomposition in the fynbos biome of South Africa, attributing this to rapid leaching of such substances out of the litter (Schönholzer and others 1998). Furthermore, some groups of soil animals (e.g. termites and earthworms) can partly digest secondary metabolites (Hättenschwiler and Vitousek 2000), and thus their activity may not be inhibited by such compounds, precluding effects of polyphenols on the rate of decomposition. Crude protein content is also perhaps less important for invertebrate herbivores than vertebrate ones, and thus not a critical determinant for decomposition rates. Indeed, Radford and Andersen (2012) found that invertebrate population trends following fire events in Australian savanna did not correspond to changes in grass quality (including protein content), recovering much faster than grass nutrition levels. Thus, although litter quality does influence decomposition rates (U. mosambicensis decomposed the fastest) this is only discernible when litter quality is exceptionally high; at lower quality levels the effects are negligible.

The significant interaction terms in our model indicate that different factors are important in different areas and seasons. At the driest site (Mopani), neither seasonality nor litter quality affected decomposition, however, with increasing mean annual precipitation; season becomes an increasingly important factor for high quality litter. In arid regions such as Mopani, rainfall is sporadic and insufficient to sustain large populations of decomposer invertebrates or fungi, resulting in neither seasonality nor quality being important here. Tian and others (2007) recorded a similar pattern in west Africa, where high quality litter decomposed faster in wetter regions only and similar results (no effect of season or litter quality) were also recorded in arid New Mexico during a long-term decomposition study (Vanderbilt and others 2008). In such areas, factors other than water availability and litter 
quality need to be considered in relation to litter decomposition (Austin 2011).

Photodegradation is likely to be relatively more important here; indeed Mlambo and Mwenje (2010) found that photodegradation was an important agent of tree litter decay in mopane woodland, and other studies have demonstrated that it is the most important mechanism in arid regions (Austin and Vivanco 2006; Henry and others 2008; Gallo and others 2008; Brandt 2010 and others 2010).

Seasonality is important for high quality litter, but not for low quality litter, this being particularly evident with $U$. mosambicensis. We suggest that this may be due to decomposer invertebrates favouring high quality litter (U. mosambicensis); since they would be more active during the wet season, rapid mass loss of high quality grass would occur then. However, when such organisms become inactive during the dry season, high quality litter is not removed by them and thus does not decompose any faster than low quality litter.

\section{The effect of fire regime}

Overall, fire regime had no significant effect on decomposition rate, which is partly expected given the high levels of resistance to burning shown by other savanna attributes (see Parr and Andersen 2006). However, our results indicate that the effect of fire regimes on the decomposition process is much more complex than shown in previous studies; and this is because the magnitude and direction of the effects varied with mean annual precipitation and litter quality. In the most arid region, Mopani, burning had no effect, demonstrating the exceptionally high resistance to disturbance of both biodiversity and ecosystem processes in these arid regions. Indeed, apart from temperature, none of the other recorded variables showed differences between fire regimes. At these same sites, Davies and others (2012) and Parr and others (2004) found similarly high resistance to fire for termites and ants respectively, with little difference in diversity and composition across fire regimes. Our 
results suggest, therefore, that in such systems, ecosystem function responses to fire closely match faunal responses.

In the less arid savanna habitats, fire regime had significant effects on decomposition rates. At Satara (semi-arid to intermediate rainfall), faster levels of decomposition were recorded on burnt than unburnt sites. Although no direct data related to termite decomposition are available, termite activity was higher on burnt sites (Fig. 4b), and given the important role they play as decomposers, we hypothesise that higher rates of decomposition on frequently burnt plots may be a result of increased termite activity. Frequent fire in these savannas leads to an increase in fungus-growing termite activity with a concomitant increase in decomposition rate (the combined effect of fungus-growing termites outcompeting fungi, and greater nutrient cycling due to increased grazing activity, enhances termite activity, see Davies and others 2012). The highest quality grass litter ( $U$. mosambicensis) showed the greatest differences in decomposition rate across the burning regimes, hence driving the pattern and the interaction between litter quality and fire regime. Thus, some litter types are affected by fire, but not others; possibly due to termites favouring high quality litter and being more abundant on frequently burnt plots.

In contrast, at the wetter savanna sites (Pretoriuskop and Hluhluwe), decomposition generally took place more rapidly on unburnt sites with frequent fire slowing decomposition; there was also no noticeable interaction between fire regime and litter quality. The higher decomposition rate on unburnt sites is likely to be because in systems with no, or low fungusgrower termite abundance, other factors are more important for determining decomposition rates. Silveira and others (2009) found that fire slowed decomposition in seasonal Amazonian forest, a system with no fungus-growing termites present, and attributed this to an altered, drier microclimate: temperature increased and humidity decreased as a result of an opening up of the canopy by frequent fire, producing an unfavourable environment for soil animals 
and microbial communities, particularly as they may normally be adapted to a more buffered microclimate. The joint effect of fewer fungus-growing termites and the lower canopy cover (which alters microclimate) on burnt plots at Pretoriuskop are thus likely to contribute to slower decomposition. Other studies (e.g., Brennan and others 2009) found that slowed decomposition under high frequency fire regimes was a result of the detrimental effects of fire on decomposer organisms. Although fire had little effect on fungus-growing termites (major savanna decomposers) at these wetter sites (Figure 4a,b and Davies and others 2012), burning may have reduced the diversity of other non-termite litter-consumers, including fungi, that are more abundant in wetter, more humid environments (Aanen and Eggleton 2005). Indeed, Brennan and others (2009) attribute changes to decomposition rate by fire to such non-termite invertebrate groups. At our wetter sites, fungus-growing termite diversity was lower than at the intermediate rainfall sites (Fig. 4a and Davies and others 2012). Consequently, we suggest that when mesic savanna sites are frequently burnt, decomposition rates decrease because other invertebrate groups (including non-fungus-growing termites) and fungi are negatively affected, and fungus-growing termites are not sufficiently abundant to come into prominence and increase decomposition rates (see Fig. 5 for a conceptual model hypothesising how burning interacts with mean annual precipitation to affect decomposition).

\section{Conclusions and future directions}

We conclude that, in line with global models, the rate of grass decomposition in African savannas is primarily governed by the effects of climate and litter quality on decomposer activity. Although much of this decomposition is likely to be microbial, we hypothesise that the role of larger decomposer organisms (particularly fungus-growing termites) may become important at local scales in areas of intermediate rainfall (e.g. Satara) where moisture levels are low enough to limit external microbial decomposition, but not too low to constrain 
termite activity. This then facilitates the dominance of fungus-growing termites where they can out-compete free-living fungi (Aanen and Eggleton 2005). Disturbance regimes (fire) also play an important role locally in mediating decomposition under certain climatic and litter quality conditions; this is likely to be through effects on termite activity, vegetation structural, and hence microclimatic, alterations, and possible effects on the diversity of other invertebrates, with the direction of these effects dependent on the amount of mean annual precipitation received (see Fig. 5).

Southern African savannas are predicted to become wetter with future climate change (Senior and others 2002). Consequently, following our results, overall faster rates of decomposition can be expected, potentially resulting in a reduced ability to store carbon and consequently an increased rate of carbon return to the atmosphere. Furthermore, under global change models and increased human population pressure, fires are likely to become more frequent (Williams and others 2009). Since fire regime has an effect on decomposition in all but the most arid savanna habitats, shifts in decomposition rates can be expected. Frequent fire was found to slow decomposition in wetter savannas, meaning that across many savanna areas increased fire occurrence could result in slower decomposition. Conversely, in arid or semi-arid savannas where fire increases decomposition rates the opposite could occur, leading to increased carbon turnover rates. Changing climate and fire regimes may thus act in opposite directions to affect decomposition, but currently we do not have enough data to predict accurately which, if either, will be most influential. Further studies are required to test more explicitly the ideas presented here, particularly to unravel the roles of termites and other factors in savanna decomposition using appropriate multiple mesh size litter bag exclusion experiments. Shading experiments will also be useful to elucidate the relative importance of photodegradation in these systems and interactions between processes (e.g. infrequent fire in mesic savannas increases woody cover which reduces light penetration to ground layer). Such 
research will improve our understanding of the mechanistic processes influencing decomposition under different fire-regimes, and enable more accurate predictions for future ecosystem changes.

\section{Acknowledgements}

We are grateful to the Trapnell Fund, the Rufford Small Grants, the Centre for Invasion Biology, and the University of Pretoria for research funding. We especially thank William Bond and the Zululand Tree Project for assistance with sampling in Hluhluwe. KZN-Wildlife and SANParks are thanked for project support and permission to work in the parks. William Bond, Amy Austin and two anonymous reviewers are also thanked for their valuable comments on earlier versions of the manuscript. Field and laboratory assistants, in particular Sonja Streicher and Ingrid van der Merwe, are gratefully acknowledged for their assistance.

\section{References}

Aanen DK, Eggleton P. 2005. Fungus-growing termites originated in African rain forest. Curr Biol 15:851-855.

Aerts R. 1997. Climate, leaf litter chemistry and leaf litter decomposition in terrestrial ecosystems: a triangular relationship. Oikos 79:439-449.

Austin AT. 2011. Has water limited our imagination for aridland biogeochemistry? Trends Ecol Evol 26:229-235.

Austin AT, Vivanco L. 2006. Plant litter decomposition in a semi-arid ecosystem controlled by photodegradation. Nature 442:555-558.

Ayres E, Steltzer H, Berg S, Wall DH. 2009. Soil biota accelerate decomposition in highelevation forests by specializing in the breakdown of litter produced by the plant species above them. J Ecol 97:901-912. 
Bengtsson J, Janion C, Chown SL, Leinaas HP. 2011. Variation in decomposition rates in the fynbos biome, South Africa: the role of plant species and plant stoichiometry. Oecologia 165:225-235.

Biggs R, Biggs HC, Dunne TT, Govender N, Potgieter ALF. 2003. Experimental burn plot trial in the Kruger National Park: history, experimental design and suggestions for data analysis. Koedoe 46:1-15.

Bond WJ, Keeley JE. 2005. Fire as a global 'herbivore': the ecology and evolution of flammable ecosystems. Trends Ecol Evol 20:387-394.

Bond WJ, Woodward FI, Midgley GF. 2005. The global distribution of ecosystems in a world without fire. New Phytologist 165:525-538.

Bond WJ, Parr CL. 2010. Beyond the forest edge: Ecology, diversity and conservation of the grassy biomes. Biol Conserv 143:2395-2404.

Bowers JA. 2006. Feeding Patch Selection of African Buffalo (Syncerus caffer caffer) in the Central Region of the Kruger National Park. Masters thesis, Tshwane University of Technology.

Brandt LA, King JY, Hobbie SE, Milchunas DG, Sinsabaugh RL. 2010. The role of photodegradation in surface litter decomposition across a grassland ecosystem precipitation gradient. Ecosystems 13:765-781.

Brennan KEC, Christie FJ, York A. 2009. Global climate change and litter decomposition: more frequent fire slows decomposition and increases the functional importance of invertebrates. Global Change Biol 15:2958-2971.

Buis GM, Blair JM, Burkepile DE, Burns CE, Chamberlain AJ, Chapman PL, Collins SL, Fynn RWS, Govender N, Kirkman KP, Smith MD, Knapp AK. 2009. Controls of aboveground net primary production in mesic savanna grasslands: an interhemispheric comparison. Ecosystems 12:982-995. 
Buitenwerf R, Stevens N, Gosling CM, Anderson TM, Olff H. 2011. Interactions between large herbivores and litter removal by termites across a rainfall gradient in a South African savanna. J Trop Ecol 27:375-382.

Cary GJ. 2002. Importance of a changing climate for fire regimes in Australia. In: Bradstock RA, Williams JE, Gill AM, Eds. Flammable Australia: The fire regimes and biodiversity of a continent. Cambridge: Cambridge University Press. p 26-46.

Chapin FS, Matson PA, Mooney HA. 2002. Principles of Terrestrial Ecosystem Ecology. New York: Springer.

Collins NM. 1981. The role of termites in the decomposition of wood and leaf litter in the Southern Guinea savanna of Nigeria. Oecologia 51:389-399.

Couteaûx M-M, Bottner P, Berg B. 1995. Litter decomposition, climate and litter quality. Trends Ecol Evol 10:63-66.

Curry JP. 1998. Factors affecting earthworm abundance in soils. In: Edwards CA, Ed. Earthworm ecology. Boca Raton: CRC Press. p. 37-64.

Davies AB. 2010. Termite responses to long term burning regimes in southern African savannas: patterns, processes and conservation. Masters thesis, University of Pretoria.

Davies AB, Parr CL, van Rensburg BJ. 2010. Termites and fire: Current understanding and future research directions for improved savanna conservation. Austral Ecol 35:482486.

Davies AB, Eggleton P, van Rensburg BJ, Parr CL. 2012. The pyrodiversity-biodiversity hypothesis: a test with savanna termite assemblages. J Appl Ecol 49:422-430.

Dawes-Gromadzki TZ. 2003. Sampling subterranean termite species diversity and activity in tropical savannas: an assessment of different bait choices. Austral Ecol 18:397-404. 
Dawes-Gromadzki TZ, Spain A. 2003. Seasonal patterns in the activity and species richness of surface-foraging termites (Isoptera) at paper baits in a tropical Australian savanna. J Trop Ecol 19:449-456.

Ellis RP. 1990. Tannin-like substances in grass leaves. Memoirs of the Botanical Survey of South Africa 59:59-77.

Flannigan MD, Stocks BJ, Wooton BM. 2000. Climate change and forest fires. Sci Total Environ 262:221-229.

Freymann BP, De Visser SN, Olff H. 2010. Spatial and temporal hotspots of termite-driven decomposition in the Serengeti. Ecography 33:443-450.

Gallo ME, Porras-Alfaro A, Odenbach KJ, Sinsabaugh RL. 2008. Photoacceleration of plant litter decomposition in an arid environment. Soil Biol Biochem 41: 1433-1441.

Garnsey R. 1994. Seasonal activity and estivation of lumbricid earthworms in the midlands of Tasmania. Soil Research 32:1355-1367.

Gholz HL, Wedin DA, Smitherman SM, Harmon ME, Parton WJ. 2000. Long-term dynamics of pine and hardwood litter in contrasting environments: toward a global model of decomposition. Global Change Biol 6:751-765.

Goldammer JG, Price C. 1998. Potential impacts of climate change on fire regimes in the tropics based on MAGICC and a GISS CCM-derived lightening model. Climatic Change 39:273-296.

Hättenschwiler S, Gasser P. 2005. Soil animals alter plant litter diversity effects on decomposition. P Natl Acad Sci USA 102:1519-1524.

Hättenschwiler S, Tiunov AV, Scheu S. 2005. Biodiversity and litter decomposition in terrestrial ecosystems. Annu Rev Ecol Evol S. 36:191-218.

Hättenschwiler S, Vitousek PM. 2000. The role of polyphenols in terrestrial ecosystem nutrient cycling. Trends Ecol Evol 15:238-243. 
Henry HAL, Brizgys K, Field CB. 2008. Litter decomposition in a California annual grassland: interactions between photodegradation and litter layer thickness. Ecosystems 11: 545-554.

Hernández D, Hobbie S. 2008. Effects of fire frequency on oak litter decomposition and nitrogen dynamics. Oecologia 158:535-543.

Holt JA, Coventry RJ. 1990. Nutrient cycling in Australian savannas. J Biogeogr 17:427 432.

Hughes L. 2003. Climate change and Australia: trends, projections and impacts. Austral Ecol $28: 423-443$.

Kay AD, Mankowski J, Hobbie SE. 2008. Long-term burning interacts with herbivory to slow decomposition. Ecology 89:1188-1194.

Krawchuk MA, Moritz MA, Parisien MA, Van Dorn J, Hayhoe K. 2009. Global pyrogeography: the current and future distribution of wildfire. Plos One 4:e5102.

La Fage JP, Nutting WL, Haverty MI. 1973. Desert subterranean termites: A method for studying foraging behavior. Environ Entomol 2:954-956.

Lavelle P, Blanchart E, Martin A, Martin S, Spain A, Toutain F, Barois I, Schaefer R. 1993. A hierarchical model for decomposition in terrestrial ecosystems: application to soils of the humid tropics. Biotropica 25:130-150.

Macandza VA, Owen-Smith N, Cross PC. 2004. Forage selection by African buffalo in the late dry season in two landscapes. S Afr J Wildl Res 34:113-121.

Meentemeyer V. 1978. Macroclimate and lignin control of litter decomposition rates. Ecology 59:465-472.

Mlambo D, Mwenje E. 2010. Influence of Colophospermum mopane canopy cover on litter decomposition and nutrient dynamics in a semi-arid African savannah. Afr J Ecol 48:1021-1029. 
Murphy KL, Klopatek JM, Klopatek CC. 1998. The effects of litter quality and climate on decomposition along an elevational gradient. Ecol Appl 8:1061-1071.

Ohiagu CE, Wood TG. 1979. Grass production and decomposition in Southern Guinea savanna, Nigeria. Oecologia 40:155-165.

Olson JS. 1963. Energy storage and the balance of producers and decomposers in ecological systems. Ecology 44:322-331.

Parr C L, Chown SL. 2003. Burning issues for conservation: A critique of faunal fire research in Southern Africa. Austral Ecol 28:384-395.

Parr CL, Andersen AN. 2006. Patch mosaic burning for biodiversity conservation: a critique of the pyrodiversity paradigm. Conserv Biol 20:1610-1619.

Parr CL, Robertson HG, Biggs HC, Chown SL. 2004. Response of African savanna ants to long-term fire regimes. J Appl Ecol 41:630-642.

Powers JS, Montgomery RA, Adair EC, Brearley FQ, DeWalt SJ, Castanho CT, Chave J, Deinert E, Ganzhorn JU, Gilbert ME, González-Iturbe JA, Bunyavejchewin S, Grau HR, Harms KE, Hiremath A, Iriarte-Vivar S, Manzane E, De Oliveira AA, Poorter L, Ramanamanjato J-B, Salk C, Varela A, Weiblen GD, Lerdau MT. 2009. Decomposition in tropical forests: a pan-tropical study of the effects of litter type, litter placement and mesofaunal exclusion across a precipitation gradient. J Ecol 97:801-811

R Development Core Team. 2010. R: A Language and Environment for Statistical Computing. R Foundation for Statistical Computing, Vienna. Available at: http://www.r-project.org.

Radford IJ, Andersen AN. 2012. Effects of fire on grass-layer savanna macroinvertebrates as key food resources for insectivorous vertebrates in northern Australia. Austral Ecol $37: 733-742$ 
Rastetter EB, Ryan MG, Shaver GR, Melillo JM, Nadelhoffer KJ, Hobbie JE, Aber JD. 1991. A general biogeochemical model describing the responses of the $\mathrm{C}$ and $\mathrm{N}$ cycles in terrestrial ecosystems to changes in CO2, climate, and $\mathrm{N}$ deposition. Tree Physiol 9:101-126.

Sayer EJ. 2006. Using experimental manipulation to assess the roles of leaf litter in the functioning of forest ecosystems. Biol Rev 81:1-31.

Schimel DS, Alvves D, Enting I, Heimann M, Joos F, Raymond D, Wigley T. 1996. CO 2 and the carbon cycle. In: Houghton J, Filho LM, Callander BA, Harris N, Kattenberg A, Maskell K, Eds. Climate change 1995. Cambridge: Cambridge University Press. p.7686.

Scholes RJ, Archer SR. 1997. Tree-grass interactions in savannas. Annu Rev Ecol Syst 28:517-544.

Schönholzer F, Kohli L, Hahn D, Daniel O, Goez C, Zeyer J. 1998. Effects of decomposition of leaves on bacterial biomass and on palatability to Lumbricus terrestris L. Soil Biol Biochem 30:1805-1813.

Schuurman G. 2005. Decomposition rates and termite assemblage composition in semiarid Africa. Ecology 86:1236 - 1249.

Senior CA, Jones RG, Lowe JA, Durman CF, Hudson D. 2002. Predictions of extreme precipitation and sea-level rise under climate change. Philos T R Soc S-A 360:13011311.

Silveira JM, Barlow J, Krusche AV, Orwin KH, Balch JK, Moutinho P. 2009. Effects of experimental fires on litter decomposition in a seasonally dry Amazonian forest. $\mathrm{J}$ Trop Ecol 25:657-663.

Smith JL, Rust MK. 1994. Temperature preferences of the western subterranean termite, Reticulitermes hesperus Banks. J Arid Environ 28:313-323. 
Survey of economic plants for arid and semi-arid lands (SEPASAL) database. 1999. Royal Botanic Gardens, Kew. Published on the Internet;

http://apps.kew.org/sepasalweb/sepaweb [accessed 20/07/2012; 14h30].

Swift MJ, Heal OW, Anderson JM. 1979. Decomposition in Terrestrial Ecosystems. Berkeley: University of California Press.

Taylor AR, Schröter D, Pflug A, Wolters V. 2004. Response of different decomposer communities to the manipulation of moisture availability: potential effects of changing precipitation patterns. Global Change Biol 10:1313-1324.

Tian G, Badejo M, Okoh A, Ishida F, Kolawole G, Hayashi Y, Salako F. 2007. Effects of residue quality and climate on plant residue decomposition and nutrient release along the transect from humid forest to Sahel of West Africa. Biogeochemistry 86:217-229.

Vanderbilt KL, White CS, Hopkins O, Craig JA. 2008. Aboveground decomposition in arid environments: results of a long-term study in central New Mexico. J Arid Environ 72:696-709.

Van de Vijver CADM, Poot P, Prins HHT. 1999. Causes of increased nutrient concentrations in post-fire regrowth in an East African savanna. Plant Soil 214:173-185.

Wall DH, Bradford MA, St. John MG, Trofymow JA, Behan-Pelletier V, Bignell DE, Dangerfield JM, Parton WJ, Rusek J, Voigt W, Wolters V, Gardel HZ, Ayuke FO, Bashford R, Beljakova OI, Bohlen PJ, Brauman A, Flemming S, Henschel JR, Johnson DL, Jones TH, Kovarova M, Kranabetter JM, Kutny LES, Lin K-C, Maryati M, Masse D, Pokarzhevskii A, Rahman H, SabarÁ MG, Salamon J-A, Swift MJ, Varela A, Vasconcelos HL, White DON, Zou X. 2008. Global decomposition experiment shows soil animal impacts on decomposition are climate-dependent. Global Change Biol 14:2661-2677. 
Whitford WG, Steinberger Y, Ettershank G. 1982. Contributions of subterranean termites to the "economy" of Chihuahuan desert ecosystems. Oecologia 55:298-302.

Williams RJ, Bradstock RA, Cary GJ, Enright NJ, Liedlof AM, Lucas C, Whelan RJ, Anderson AN, Bowman DMJS, Clarke PJ, Cook GD, Hennessy KJ, York A. 2009. Interactions between climate change, fire regimes and biodiversity in Australia: a preliminary assessment. Department of Climate Change, Canberra. 
Table 1: Estimates of percentage crude protein content and palatability of the four grass species used in this study. The species represent a gradient of litter quality from low $(C$. excavatus) to very high (U. mosambicensis).

\begin{tabular}{lll}
\hline Grass species & Crude protein & Palatability \\
& content $(\%)$ &
\end{tabular}

Cymbopogon excavatus $\quad 6.19^{\mathrm{a}} \quad$ Poor $^{\mathrm{b}, \mathrm{c}, \mathrm{d}, \mathrm{e}}$

Themeda triandra $\quad 6.90^{\mathrm{a}}, 5.3-10.4^{\mathrm{b}} \quad$ Moderate $^{\mathrm{c}, \mathrm{d}, \mathrm{e}}-$ High $^{\mathrm{b}}$

Cenchrus ciliaris $\quad 12.00^{\mathrm{a}}, 7.4-12.27^{\mathrm{b}} \quad \operatorname{High}^{\mathrm{b}, \mathrm{c}, \mathrm{e}}$

Urochloa mosambicensis $\quad 13.83^{\mathrm{a}}, 10-20^{\mathrm{b}} \quad$ Very high $^{\mathrm{b}, \mathrm{e}}$

References: a - Bowers 2006; b - Survey of economic plants for arid and semi-arid lands (SEPASAL) database (1999); c - Macandza and others 2004; d - Fourie and others 1985; e van Oudtshoorn 2006 
Table 2: Statistical (GLM) analysis of decomposition rate ( $k$ values) in relation to the fixed factors precipitation, season, litter quality and fire regime. Asterisks $\left(^{*}\right)$ signify statistical significance, $*=p<0.05, * *=p<0.01, * * *=p<0.001$.

\begin{tabular}{|c|c|c|c|}
\hline Factor & $d f$ & $F$ & $P$ \\
\hline Precipitation & 3 & 42.92 & $<0.0001 * * *$ \\
\hline Season & 1 & 42.23 & $<0.0001 * * *$ \\
\hline Litter quality & 3 & 52.99 & $<0.0001 * * *$ \\
\hline Fire regime & 1 & 0.87 & 0.3523 \\
\hline Precipitation x Season & 3 & 2.23 & 0.0840 \\
\hline Precipitation x Litter quality & 9 & 1.94 & $0.0449 *$ \\
\hline Precipitation $\mathrm{x}$ Fire regime & 3 & 10.10 & $<0.0001 * * *$ \\
\hline Season $\mathrm{x}$ Litter quality & 3 & 24.09 & $<0.0001 * * *$ \\
\hline Season $\mathrm{x}$ Fire regime & 1 & 1.30 & 0.2552 \\
\hline Litter quality x Fire regime & 3 & 4.83 & $0.0025 * *$ \\
\hline Precipitation $\mathrm{x}$ Season $\mathrm{x}$ Litter quality & 9 & 1.41 & 0.1819 \\
\hline Precipitation $\mathrm{x}$ Season $\mathrm{x}$ Fire regime & 3 & 0.92 & 0.4288 \\
\hline Precipitation $\mathrm{x}$ Litter quality $\mathrm{x}$ Fire regime & 9 & 0.86 & 0.5617 \\
\hline Season $x$ Litter quality x Fire regime & 3 & 1.37 & 0.2499 \\
\hline Precipitation $\mathrm{x}$ Litter quality $\mathrm{x}$ Season $\mathrm{x}$ Fire regime & 9 & 0.81 & 0.6092 \\
\hline
\end{tabular}




\section{List of figures}

Figure 1: Mass loss of four grass species measured as a percentage of litter remaining across four savanna types and two seasons (left: wet, right: dry season). Savanna types are arranged along a gradient of increasing mean annual precipitation. Standard error bars are smaller than data points. Data points are joined by lines for reader convenience only and do not reflect a time sequence, each point rather indicating an independent sampling event.

Figure 2: Mean ( $\pm \mathrm{SE}$ ) decomposition constants $(k)$ for four grass species (x-axis) across four savanna types in South Africa during a) the wet and b) the dry season. Savanna types are arranged along a gradient of increasing mean annual precipitation.

Figure 3: Mean $( \pm \mathrm{SE})$ decomposition constants $(k)$ of four grass species across four savanna types in South Africa on sites which were either burnt triennially (burnt) or remained unburnt (unburnt) for $c a .57$ years. Data are for both the wet and dry seasons combined. Savanna types are arranged along a gradient of increasing mean annual precipitation.

Figure 4: Mean $( \pm \mathrm{SE})$ a) termite abundance recorded with cellulose baits, b) intensity of termite attack at cellulose baits, c) temperature recorded hourly and d) canopy cover at burnt and unburnt sites in four savanna types. Sites are arranged along a gradient of increasing mean annual precipitation. An asterisk denotes a significant difference between fire regimes at each site.

Figure 5: Conceptual diagram presenting a testable hypothesis we put forward for how burning influences grass decomposition rates in southern African savannas across a gradient of mean annual precipitation (frequent burning increasing decomposition in semi-arid savannas and decreasing it in wet savanna habitats, with no effect in arid savannas). 
Figure 1
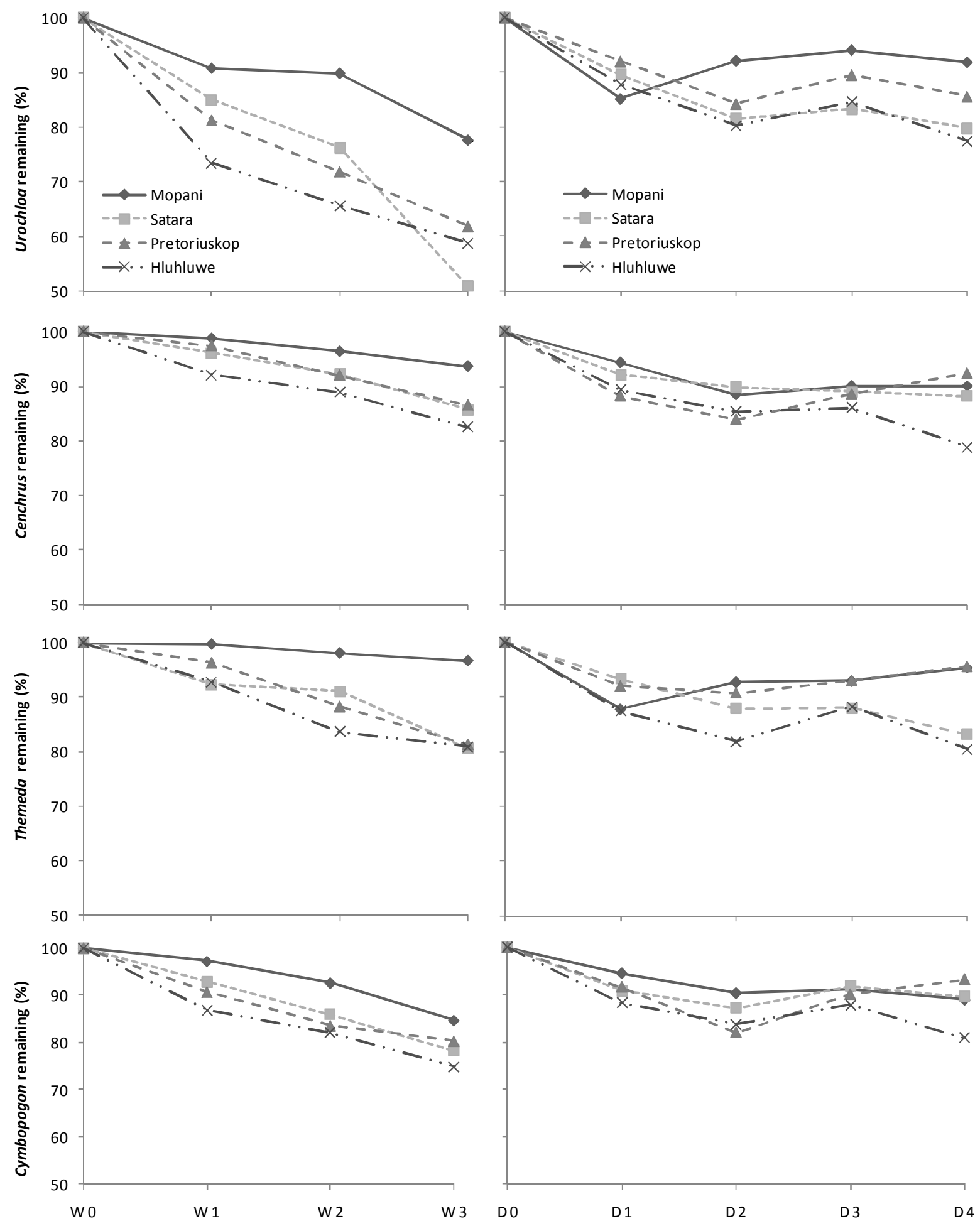

Time in months, $\mathrm{W}=$ wet; $\mathrm{D}=$ dry season 
Figure 2

a)

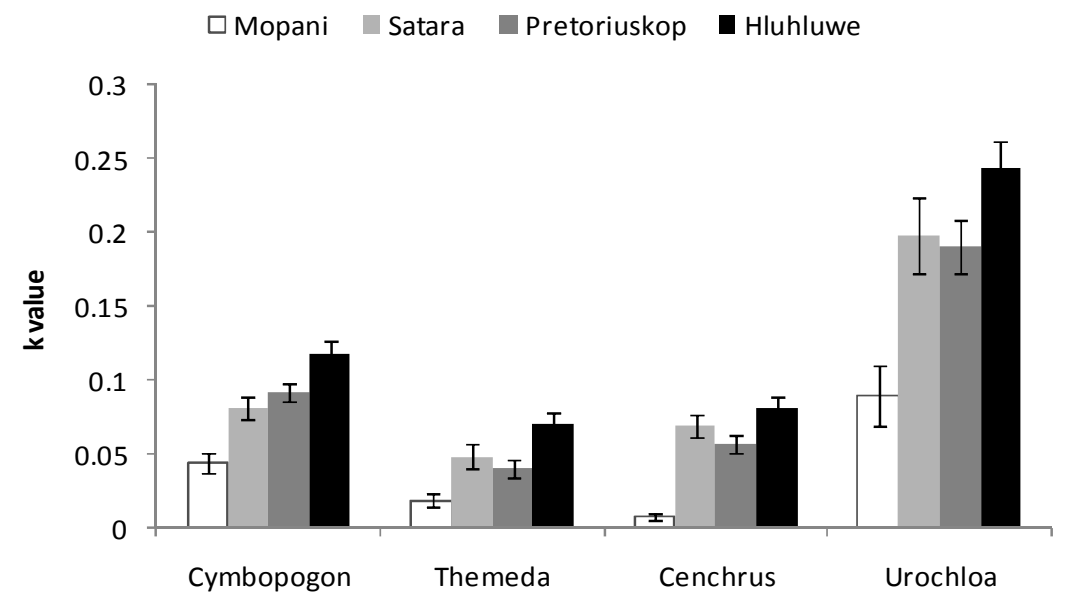

b)

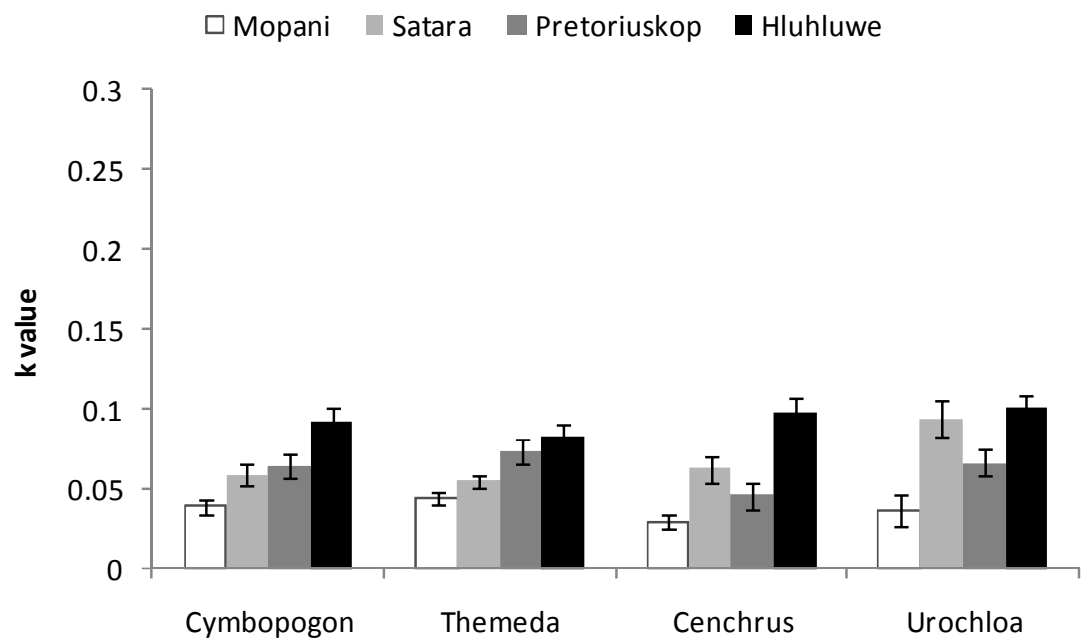


Figure 3

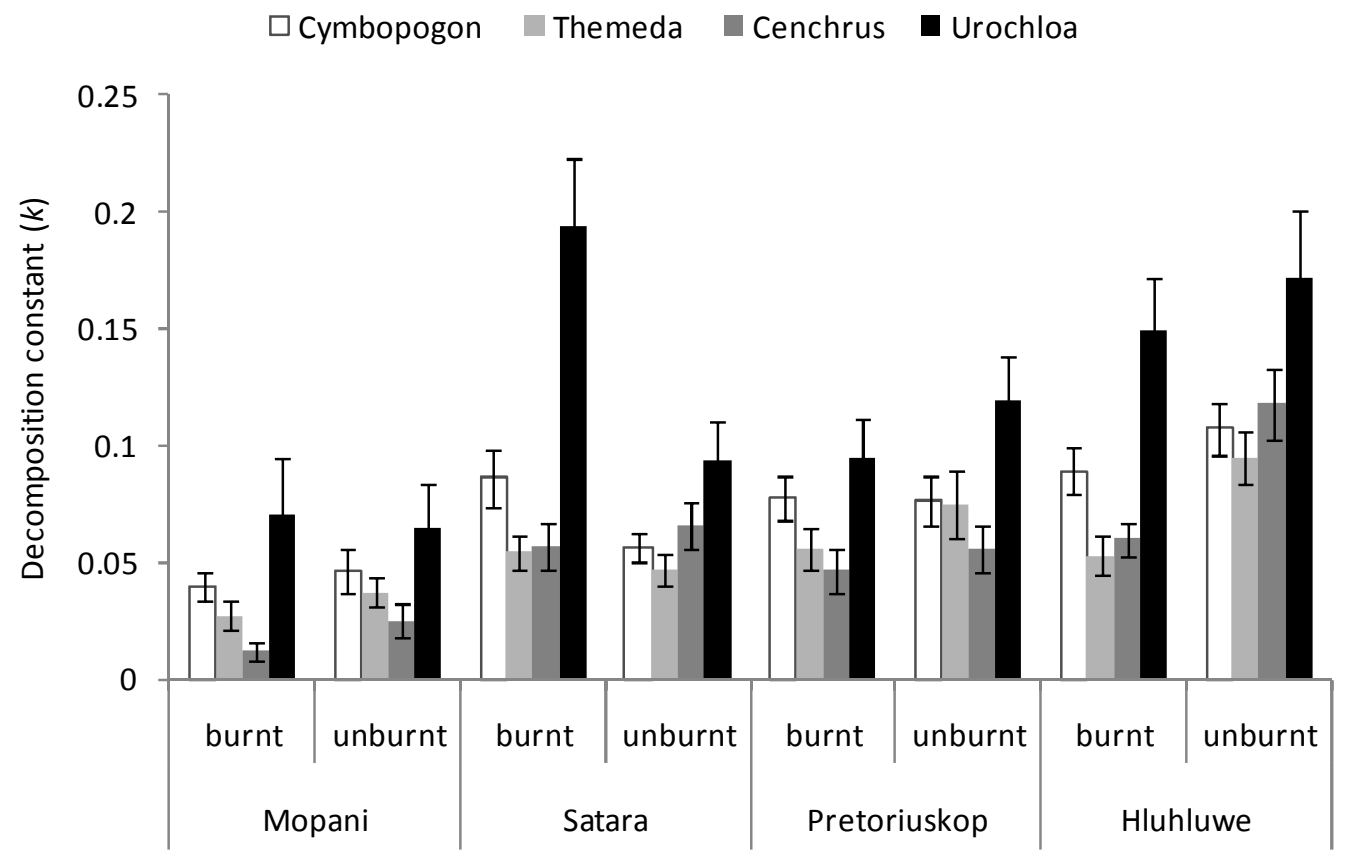

Mean annual precipitation 
Figure 4

a)

- Burnt $\square$ Unburnt

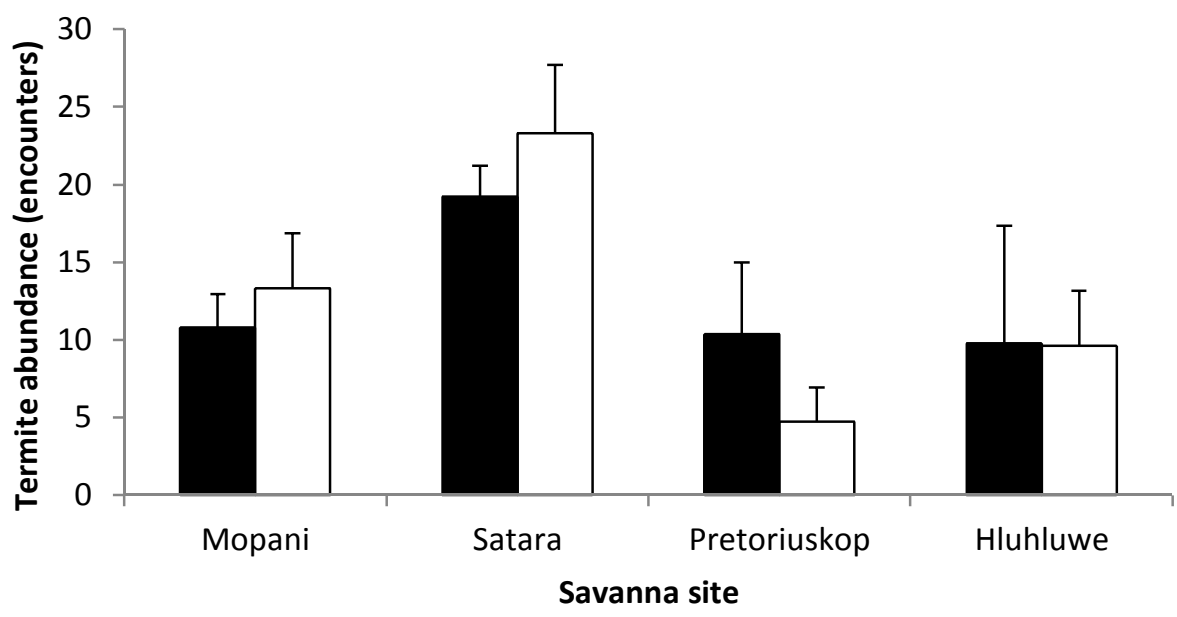

b)

- Burnt $\square$ Unburnt

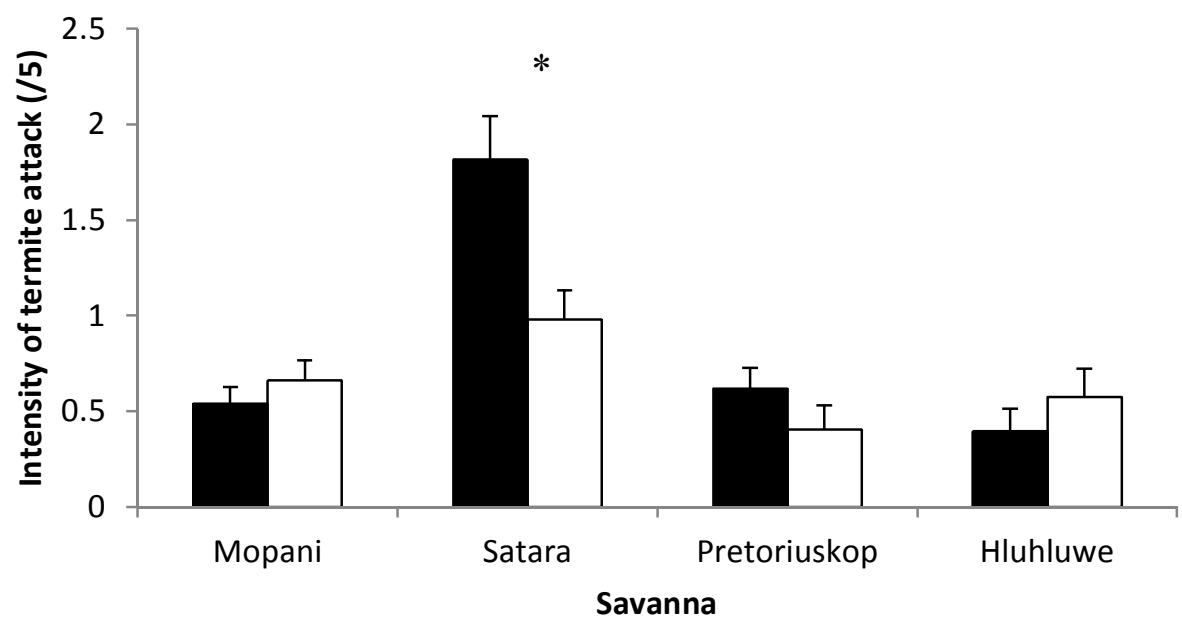


c)

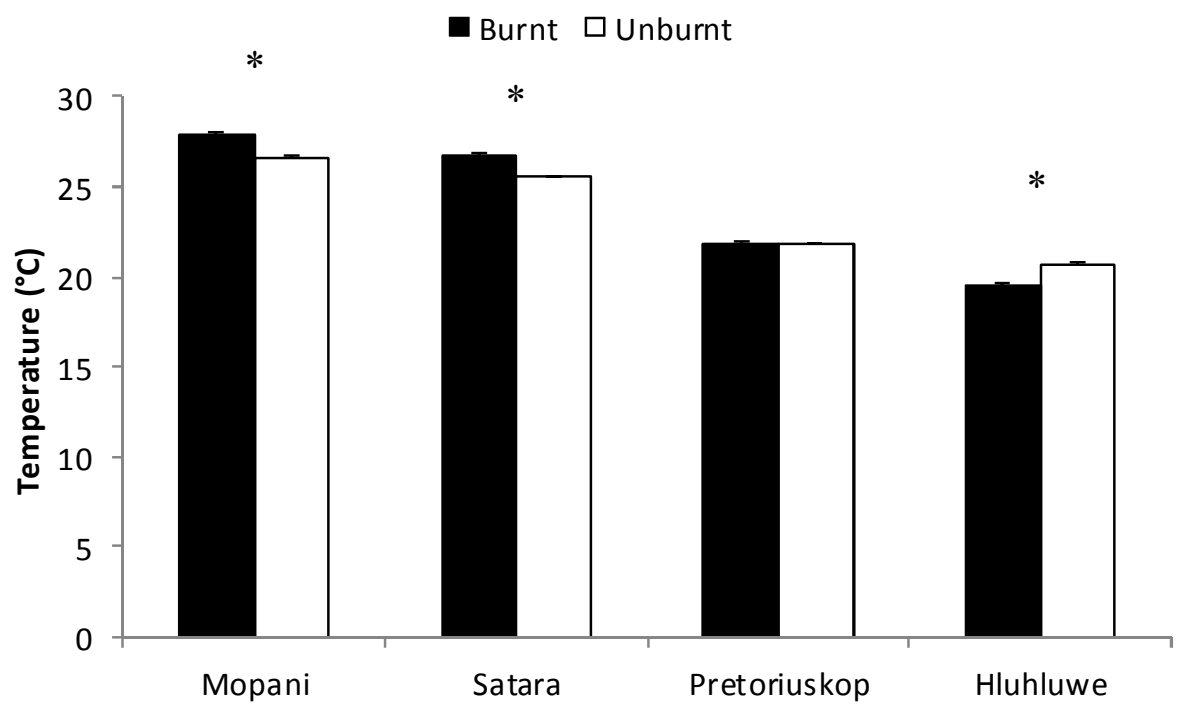

d)

- Burnt $\square$ Unburnt

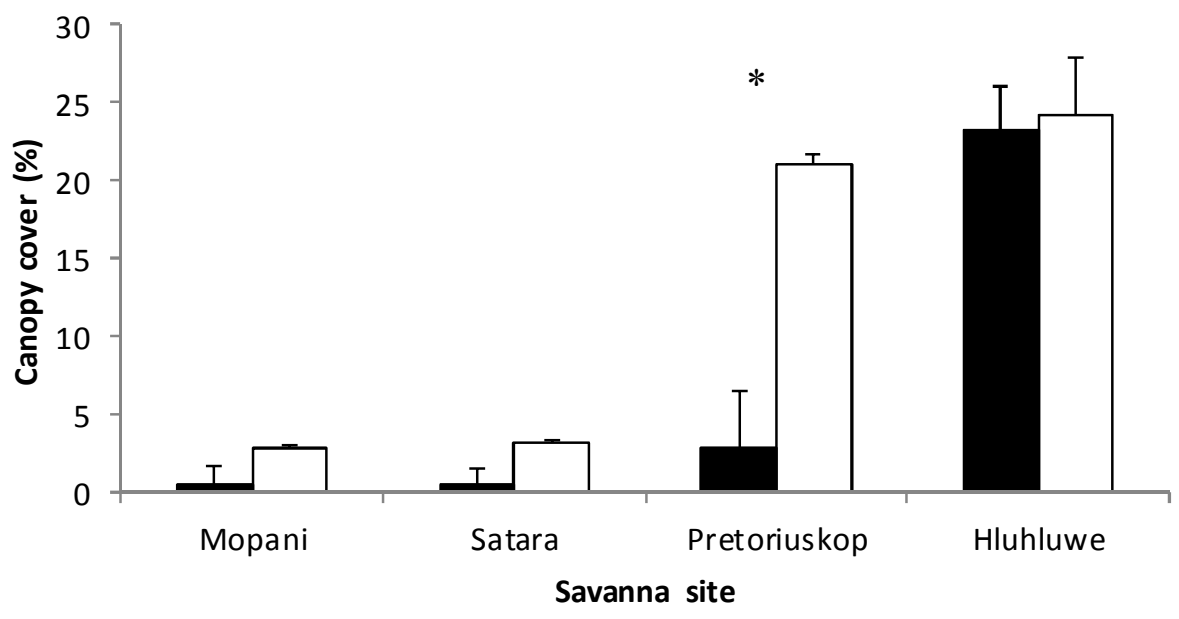


Figure 5

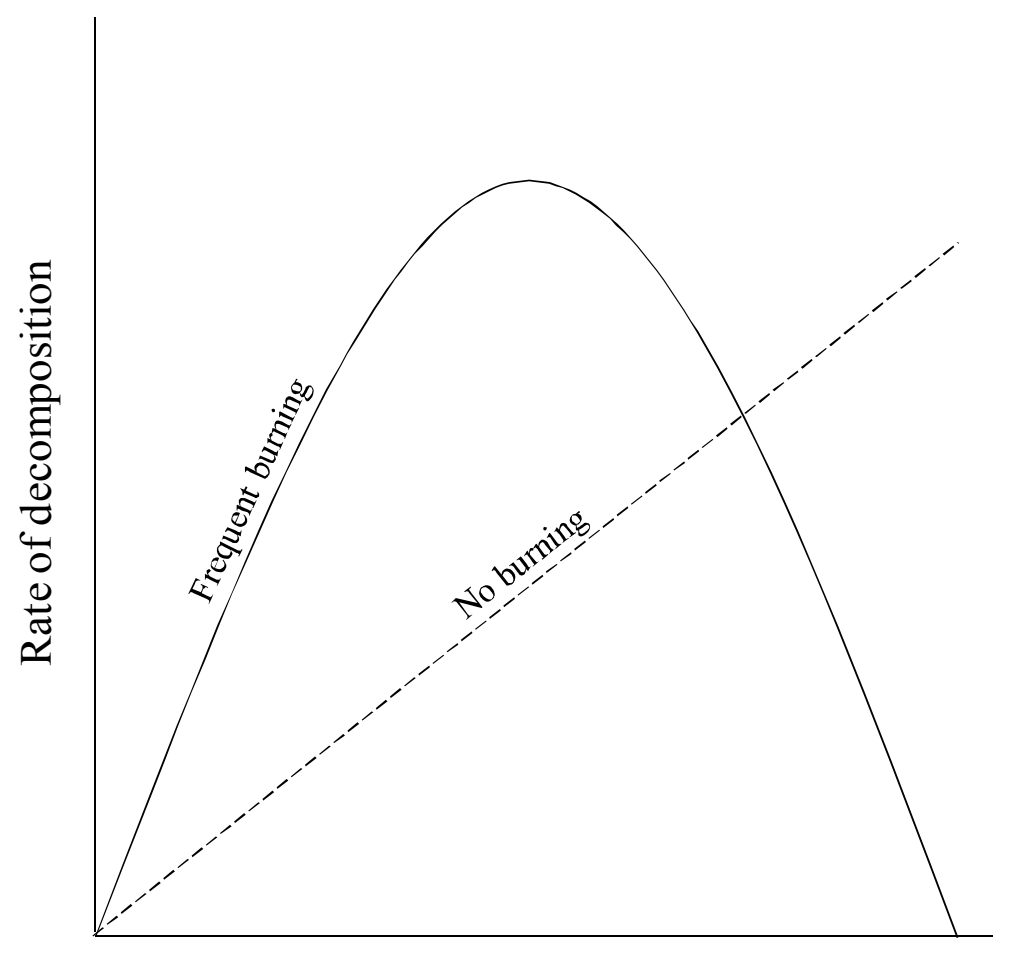

Mean annual precipitation 